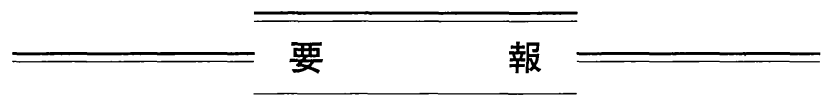

農業気象 (J.Agr. Met.) 40 (3): 263-267, 1984

\title{
Energy and Water Balance of a Pine Forest during a Bai-u and a Summer Season
}

\author{
Michiaki SUGITA \\ (Graduate Student, University of Tsukuba, )
Ibaraki 305
}

\section{Introduction}

It is important for understanding of the formation of climate in a small area to evaluate energy and water balance elements simultaneously (Yoshino, 1978). In most of the studies conducted in the forested area, however, energy balance and water balance have been measured separately. Therefore, main purpose of this study is to present the energy and water balance at the same time during a Bai-u ${ }^{1)}$ and a summer season and to discuss the results.

\section{Method}

\subsection{Study Area}

The observations were carried out at a pine forest in University of Tsukuba, $36^{\circ} 06^{\prime} \mathrm{N}$, $140^{\circ} 06^{\prime} \mathrm{E}$. The forest occupies the area of 1.9 ha and is composed mainly of Japanese Red Pine (Pinus desiflora Sieb. et Zucc.) with an average height of $10 \mathrm{~m}$, average diameter breast high of $12.4 \mathrm{~cm}$, and stand density of 27.0 trees per $100 \mathrm{~m}^{2}$. Forest floor is partly covered with understory vegetation such as lacquer tree, Japanese Oak, etc.

\subsection{Data Collection}

Elements of energy balance were measured at the center of the forest by the following apparatus mounted on the tower. Net radiation $\left(R_{n}\right)$ was measured with Funk type net radiometers (Eko Instruments Trading Co., Ltd., type CN-11) installed at heights of $1.5 \mathrm{~m}$ and $13.5 \mathrm{~m}$ above the ground surface. Sensible heat flux $(H)$ was

Read Kanto Chapter Meeting, Utsunomiya, 26 January, 1984.

Received 16 June, 1984. obtained through the eddy correlation method. Fluctuations of vertical wind speed and air temperature were measured with a sonic anemometerthermometer (Kaijo Denki Co., Ltd., type DAT100) and analyzed with a flux meter (Kaijo Denki Co., Ltd., type UDF-03). The sensor was set at a height of $13.5 \mathrm{~m}$. Soil heat flux $(G)$ was measured with a soil heat flux plate (Eko Instruments Trading Co., Ltd., type CN-9) buried at a depth of $1.0 \mathrm{~cm}$. Dry- and wet-bulb temperatures were measured with handmade ventilated psychrometers using C-C thermocouple sensors (Kojima et al., 1983) at heights of 1.0, 5.0, 8.0,10.0, and $13.5 \mathrm{~m}$, and with ventilated psychrometers using $P_{t}$ sensors (Iio Electric Co., Ltd., type $\mathrm{SH}-20$ ) at heights of 0.5 and $2.0 \mathrm{~m}$. Tree temperature was measured with $\mathrm{C}$ - C thermocouple sensor inserted into a tree trunk at a height of $4.5 \mathrm{~m}$. Wind speed was measured with 3-cup anemometers (Makino Applied Instruments, type AC-750) installed at a height of $13.0 \mathrm{~m}$. The outputs of each sensor were logged at sampling intervals of $5 \mathrm{sec}$ and averaged in every $10 \mathrm{~min}$ and printed out by a data logger (Takeda Riken Industry Co., Ltd., type TR-2731).

Gross rainfall $\left(P_{\boldsymbol{g}}\right)$, throughfall $\left(P_{t}\right)$, and stemflow $\left(P_{s}\right)$ were measured after every rainfall event. $P_{g}$ was measured with a tipping-bucket rain recorder installed at the open space. $P_{t}$ was obtained as an average of the records of 50 pottype rain gauges distributed in the rectangular plots (Majima and Tase, 1982). $P_{s}$ was measured with stemflow samplers mounted on the stems of seven pine trees at a height of $1.2 \mathrm{~m}$ (Sugita, 1984). Soil water potentials were measured with tensiometers at a depth of $10 \mathrm{~cm}$. 


\subsection{Data Analyses}

Intensive observation was carried out from July 12 to September 6, 1983. Collected data were analyzed on $10 \mathrm{~min}$ or one hour bases as follows. Evapotranspiration (ET) was obtained with the eddy correlation/energy balance method (Sugita and Kotoda, 1984): $l E T=R_{n}-G-H-S$, where $l$ is the latent heat of vaporization and $S$ is the total energy flux to storage between ground level $\left(Z_{0}\right)$ and reference level $\left(Z_{r}=13.5 \mathrm{~m}\right)$. In this study, $S$ was neglected for the calculation of hourly evapotranspiration. For 10-min values, however, $S$ is evaluated from the changes in dry- and wetbulb temperatures and tree temperature (Sugita and Kotoda, 1984): $S=S_{a}+S_{q}+S_{f}$, where $S_{a}$ and $S_{q}$ are the sensible and the latent heat fluxes to storage in air, respectively, and $S_{f}$ is the sensible heat flux to storage in pine trees. Forest floor evaporation $\left(E_{f}\right)$ is calculated on one hour basis with the Bowen ratio/energy balance method (Sugita and Kotoda, 1984): $l E_{f}=\left(R_{n}-G\right) /(1+\beta)$, where $\beta$ is the Bowen ratio. Bowen ratio was obtained by the use of the data of air temperature and vapor pressure differences between $0.5 \mathrm{~m}$ and $2.0 \mathrm{~m}$ above the ground. The following quantities were evaluated as an average in a Bai-u and a summer season. Evaporation of intercepted water $\left(E_{i}\right)$ or interception loss $(I)$ can be evaluated as $P_{g}-P_{t}-P_{s}$, transpiration $(T)$ as $E T-E_{f}-E_{i}$, and changes in subsurface water storage ${ }^{2)}\left(S_{s}\right)$ as $P_{g}-E T$.

\section{Results and Discussion}

\subsection{Energy Balance}

Fig. 1 shows the diurnal changes in energy balance elements on August 3,1983. Net radiation was used mostly as latent and sensible heat fluxes in the daytime. Bowen ratio changed from about 0.3 in the early morning to the maximum value of 0.52 at noon and then became small rapidly to 0.03 in the late afternoon. Soil heat flux was small with $G / R_{n}=2-5 \%$ for a whole day, which is coincident with the ratio of $1.2-4.9 \%$ (Hicks et al., 1975) and 3\% (Kotoda, 1982). Ratio of $S / R_{n}$ was usually $1-2 \%$, but amounted to $10-20 \%$ for both $0500 \mathrm{~h}-0600 \mathrm{~h}$ and $1800 \mathrm{~h}-1900 \mathrm{~h}$. Hence, the flux to storage may usually be negligible in the energy balance equation. Hicks et al. (1975) observed that the ratio of $S / R_{n}$ for a pine forest was usually $1.2-7.2 \%$ and accounted for $118.3 \%$ at sunset and Stewart and Thom (1973) also confirmed that storage term became the same order of magnitude as $R_{n}$ after sunrise and near sunset at a pine forest. Diurnal changes in three elements of a storage term $S$ on the same day (Aug. 3) are shown in Fig. 2. Each element is expressed as cumulative values from zero at $0010 \mathrm{~h}$. Flux to storage in trees $\left(S_{f}\right)$ had the largest diurnal range of the three and diurnal variation of $S_{f}$ showed delay of phase compared with $S_{q}$ and $S_{a}$. Fig. 3 shows the energy balance above the forest floor on Aug. 3. Because of the occur-

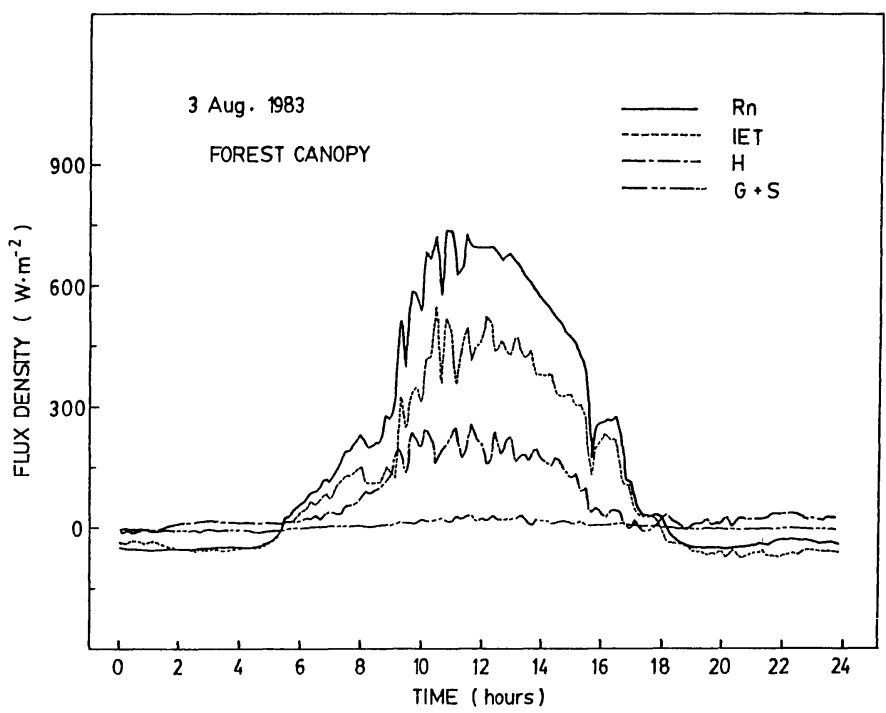

Fig. 1. Diurnal changes in energy balance elements above forest canopy. 


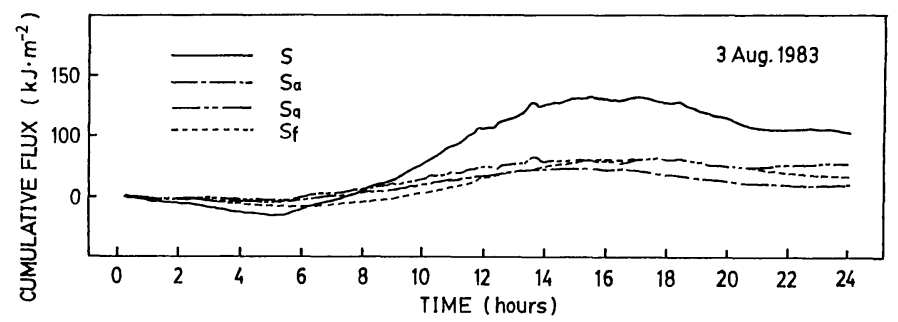

Fig. 2. Diurnal changes in energy fluxes to storage between reference level and ground surface.

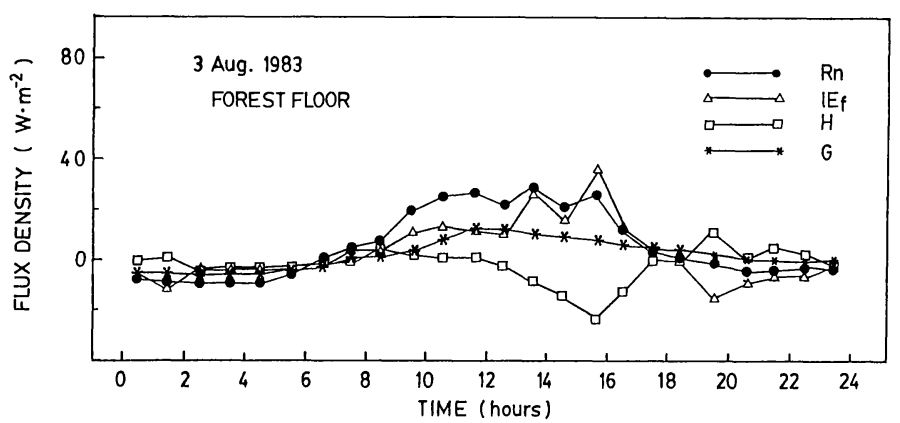

Fig. 3. Diurnal changes in energy balance elements above forest floor.

rence of downward sensible heat flux in the daytime, latent heat flux became greater than net radiation for $1500 \mathrm{~h}-1600 \mathrm{~h}$.

Average values of the energy balance elements were calculated during the observation period. In the daytime $(0600 \mathrm{~h}-1800 \mathrm{~h})$ above the forest canopy, $R_{n}$ was $232 \mathrm{~W} \cdot \mathrm{m}^{-2}$, and was used as evapotranspiration (64\%), sensible heat flux (34\%), and soil heat flux $(2 \%)$. In the nighttime $(0000 \mathrm{~h}-$ $0600 \mathrm{~h}, 1800 \mathrm{~h}-2400 \mathrm{~h}$ ), energy was lost from the pine forest as net radiation $\left(23 \mathrm{~W} \cdot \mathrm{m}^{-2}\right)$ and sensible heat flux $\left(12 \mathrm{~W} \cdot \mathrm{m}^{-2}\right)$. To compensate for these energy losses, downward latent heat flux $\left(34 \mathrm{~W} \cdot \mathrm{m}^{-2}\right)$ and upward soil heat flux $\left(1 \mathrm{~W} \cdot \mathrm{m}^{-2}\right)$ took place. A mean Bowen ratio proved to be 0.53 for $0600 \mathrm{~h}-1800 \mathrm{~h}$, when available energy $\left(R_{n}-G\right)$ was positive, and -0.35 for both $0000 \mathrm{~h}-$ $0600 \mathrm{~h}$ and $1800 \mathrm{~h}-2400 \mathrm{~h}$. Daytime value may be comparable with the ratio of $0.0-1.5$ for a Sitka Spruce (Milne, 1979), 0.49-0.84 for a Pine trees (Hicks et al., 1975), and 0.1 for Japanese Oak (Kotoda, 1982). Above the forest floor in the daytime, net radiation of $14 \mathrm{~W} \cdot \mathrm{m}^{-2}$, which was about $6 \%$ of $R_{n}$ above the forest canopy, and downward sensible heat flux of $1 \mathrm{~W} \cdot \mathrm{m}^{-2}$ were the input of energy to the floor. Seventy percent of the energy input was used for evaporation from the forest floor and 30\% entered into the soil.

\subsection{Advection}

One of the advection terms, or horizontal sensible heat flux $\left(H_{x}\right)$ was estimated with a simple method. $H_{x}$ may be expressed as

$$
H_{x}=\rho_{a} C_{p} \int_{z_{0}}^{z_{R}} u \mathrm{~d} T_{a} / \mathrm{d} x \mathrm{~d} z
$$

where $\rho_{a}$ is the density of air, $C_{p}$ the specific heat of air at constant pressure, $u$ the wind speed, and $\mathrm{d} T_{a} / \mathrm{d} x$ the horizontal gradient of air temperature. Observations of vertical wind profiles in this area showed that wind speed below the canopy was usually $5-30 \%$ of that just above the canopy. Therefore, advection proved to be most significant in the layer between $8.5 \mathrm{~m}$ and $13.5 \mathrm{~m}$ above the ground. Thus eq. (1) reduces to

$$
H_{x}=\rho_{a} C_{p} \bar{u} 5.0 \overline{\mathrm{d} T_{a} / \mathrm{d} x}
$$

where overbars denote the mean values between $8.5 \mathrm{~m}$ and $13.5 \mathrm{~m}$ above the ground. Canopy temperature was measured with the infrared thermometer. It may be sufficient to use canopy temperature as $T_{a}$ in eq. (2) for the approximate estimation of $H_{x}$, since vertical air 
temperature gradient above the canopy was kept less than $0.3^{\circ} \mathrm{C} \cdot \mathrm{m}^{-1}$ in this area even on a sunny day. Fig. 4 shows one of 20 isothermal maps of the forest canopy measured during the observation period. Table 1 shows the 10-min averaged energy balance above the forest canopy for four days selected so as to cover the various weather condition, although average wind speed greater than $2 \mathrm{~m} \cdot \mathrm{s}^{-1}$ scarcely occurred during the observation period. The values of $H_{x}$ and $H_{x} / R_{n}$ are also represented. $H_{x} / R_{n}$ is the error in determination of energy available to sensible and latent heat fluxes expected in the case of neglecting $H_{x}$. These results confirmed that horizontal sensible heat flux was of the order of $10^{0}-10^{1} \mathrm{~W} \cdot \mathrm{m}^{-2}$ at the observation point during a Bai-u and a summer season. As for the further discussion on advection term, however, direct measurements of horizontal gradients of air temperature and vapor pressure will be necessary, especially during a

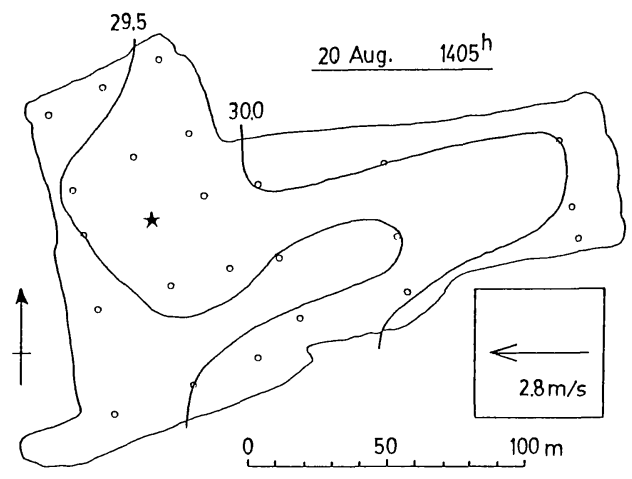

Fig. 4. Isothermal map of forest canopy. A lower right arrow and a numeral represent wind direction and wind speed, respectively. An asterisk and open circles denote observation tower and observation point, respectively. winter season when strong wind speed of monsoon is prevailing in Japan.

\subsection{Water Balance}

Table 2 shows the water balance of the pine forest for both 12 days during a Bai-u season (July 12-24) and 42 days during a summer season (July 26-Sept. 6, except for Aug. 28). During observation periods, the maximum $\mathrm{pF}$ value was 2.2 at a depth of $10 \mathrm{~cm}$, so that evapotranspiration wouldn't be suppressed by soil water shortage (Tajchman et al., 1979). In calculations of ET and $E_{f}$, upward latent heat flux was integrated for a day, as the observations showed scarce dewfall on pine tree leaves (Sugita, 1984). There may be large error in $E_{f}$ calculation with energy balance method due to large scatter of $R_{n}$ above the forest floor. Therefore, $E_{f}$ values give only an indication of order of magnitude. Stallfelt (1963) and Rutter (1966) showed by a rough

Table 2 Water balance of pine forest. Figures in the parentheses represent a daily average of each flux.

\begin{tabular}{crrrr}
\hline & July $12-24$ & \multicolumn{2}{c}{ July $26-$ Sep. 6 } \\
& \multicolumn{2}{c}{1983} & \multicolumn{2}{c}{1983} \\
\hline$P_{g}$ & 24.5 & $(1.9)$ & 207.5 & $(8.6)$ \\
$P_{t}$ & 17.4 & $(1.3)$ & 187.8 & $(7.8)$ \\
$P_{s}$ & 0.0 & $(0.0)$ & 3.0 & $(0.1)$ \\
$I$ & 7.1 & $(0.5)$ & 16.7 & $(0.7)$ \\
$E T$ & 35.2 & $(2.7)$ & 140.5 & $(5.9)$ \\
$T$ & 25.4 & $(2.0)$ & 116.1 & $(4.8)$ \\
$E_{i}$ & 7.1 & $(0.2)$ & 16.7 & $(0.7)$ \\
$E_{f}$ & 2.7 & $(0.5)$ & 7.7 & $(0.3)$ \\
$S_{s}$ & -10.7 & $(-0.8)$ & 67.0 & $(2.8)$ \\
\hline
\end{tabular}

Unit: $\mathrm{mm}\left(\mathrm{mm} \cdot \mathrm{d}^{-1}\right)$

Table 1 Energy balance above forest canopy.

\begin{tabular}{llcccc}
\hline & & $\begin{array}{c}20 \text { Aug. } \\
1405 \mathrm{~h}\end{array}$ & $\begin{array}{c}16 \mathrm{July} \\
1620 \mathrm{~h}\end{array}$ & $\begin{array}{c}29 \mathrm{July} \\
1110 \mathrm{~h}\end{array}$ & $\begin{array}{c}18 \mathrm{July} \\
1530 \mathrm{~h}\end{array}$ \\
\hline$R_{n}$ & $\left(\mathrm{~W} \cdot \mathrm{m}^{-2}\right)$ & 575 & 118 & 628 & 147 \\
$H$ & $\left(\mathrm{~W} \cdot \mathrm{m}^{-2}\right)$ & 220 & 36 & 176 & 39 \\
$l E$ & $\left(\mathrm{~W} \cdot \mathrm{m}^{-2}\right)$ & 350 & 78 & 439 & 101 \\
$U$ & $\left(\mathrm{~m} \cdot \mathrm{s}^{-2}\right)$ & 2.8 & 2.4 & 1.5 & 1.0 \\
$\mathrm{~d} T_{a} / \mathrm{d} x$ & $\left({ }^{\circ} \mathrm{C} \cdot \mathrm{m}^{-1}\right)$ & $9.7 \times 10^{-6}$ & $1.4 \times 10^{-5}$ & $9.6 \times 10^{-6}$ & $9.5 \times 10^{-6}$ \\
$H_{x}$ & $\left(\mathrm{~W} \cdot \mathrm{m}^{-2}\right)$ & 90 & 23 & 52 & 8 \\
$H_{x} / R_{n}$ & $(\%)$ & 16 & 19 & 8 & 5 \\
\hline
\end{tabular}


water balance method that $E_{f}$ accounted for 10 to $12 \%$ of $E T$ in various forests, which is the same order as the results of this study.

During a summer season, $43 \%$ of $P_{g}$ was produced by a typhoon and the number of days with precipitation was only 9 . On the contrary, during a Bai-u season, in spite of large number of days with precipitation, its amount was so small that large parts of precipitation were intercepted. It is thought that evapotranspiration became large with large interception percentages during a Bai-u season, because the evaporation rate of intercepted rainfall is about $30 \%$ faster than that of transpiration (Sugita, 1984).

\section{Acknowledgements}

I am grateful to Dr. K. Kotoda, Associate Professor of Institute of Geoscience, University of Tsukuba, for his guidance and encouragement in the course of this study. Special thanks are also extended to the staffs of Institute of Geoscience, for their suggestions and discussions. Acknowledgement is also made to Dr. S. Nakagawa, Environmental Research Center, University of Tsukuba, for his helpful discussions and critical reading of the manuscripts.

\section{Note}

1) Bai-u season is a rainy season prevailing in Japan and Middle China from early June through early or mid July.

2) Subsurface water storage is defined in this study as water stored under the ground surface.

\section{References}

1) Hicks, B. B., Hyson, P., and Moore, C. J., 1975: A study of eddy fluxes over a forest. J. Appl. Meteorol., 14, 58-66.

2) Kojima, T., Kotoda, K., and Yorisaki, A.,
1983: The handmade economical ventilated psychrometer. Bull. Environ. Res. Center, Univ. Tsukuba, 7, 27-32. (in Japanese).

3) Kotoda, K., 1982: Estimation of evapotranspiration from a deciduous forest and the turbulent transfer coefficient within canopy. Bull. Environ. Res. Center, Univ. Tsukuba, 6, 63-74. (in Japanese).

4) Majima, M. and Tase, N., 1982: Spatial variation of rainfall in a red pine forest. Bull. Environ. Res. Center, Univ. Tsukuba, 6, 75-82. (in Japanese).

5) Milne, R., 1979: Water loss and canopy resistance of a young Sitka Spruce plantation. Boundary-Layer Meteorol., 16, 67-81.

6) Rutter, A. J., 1966: Studies on the water relation of Pinus Sylvestris in plantation conditions. IV. Direct observations on the aspects of transpiration, evaporation of intercepted water, and evaporation from the soil surface. J. Appl. Ecol., 3, 393-405.

7) Stålfelt, M. G., 1963: On the distribution of the precipitation in a Spruce stand. In The Water Relations of Plants (ed. by A. J. Rutter and F. H. Whitehead). Blackwell, Oxford, 115-126.

8) Stewart, J. B. and Thom, A. S., 1973: Energy budgets in pine forest. Quart. J. R. Met. Soc., 99, 154-170.

9) Sugita, M., 1984: Evapotranspiration from a pine forest. M.S. Thesis, Univ. Tsukuba. 64p.

10) Sugita, M. and Kotoda, K., 1984: Measurement of latent heat flux over a pine forest with Bowen ratio/energy balance method and eddy correlation/energy balance method. Bull. Environ. Res. Center, Univ. Tsukuba, 8, 83-88. (in Japanese).

11) Tajchman, S., Hardrich, F., and Lee, R., 1979: Energy budget evaluation of the transpiration-pF relationship in a young pine forest. Wat. Resour. Res., 99, 154-170.

12) Yoshino, M. M., 1978: Climatology. Taimeido, Tokyo, 350p. (in Japanese).

\title{
梅雨および夏季における \\ アカマツ林の熱収支・水収支
}

\author{
杉田倫 明 \\ (筑波大学 (院) 地球科学研究科) \\ (干305 茨城県新治郡桜村天王台)
}

